Fauna of ground-dwelling arthropods in vineyards of Zadar County (Croatia)

Fauna prizemnih člankonožaca $u$ vinogradima Zadarske županije (Hrvatska)

Franin, K., Kuštera, G., Šišeta, F.

Poljoprivreda/Agriculture

ISSN: 1848-8080 (Online)

ISSN: 1330-7142 (Print)

http://dx.doi.org/10.18047/poljo.22.2.8

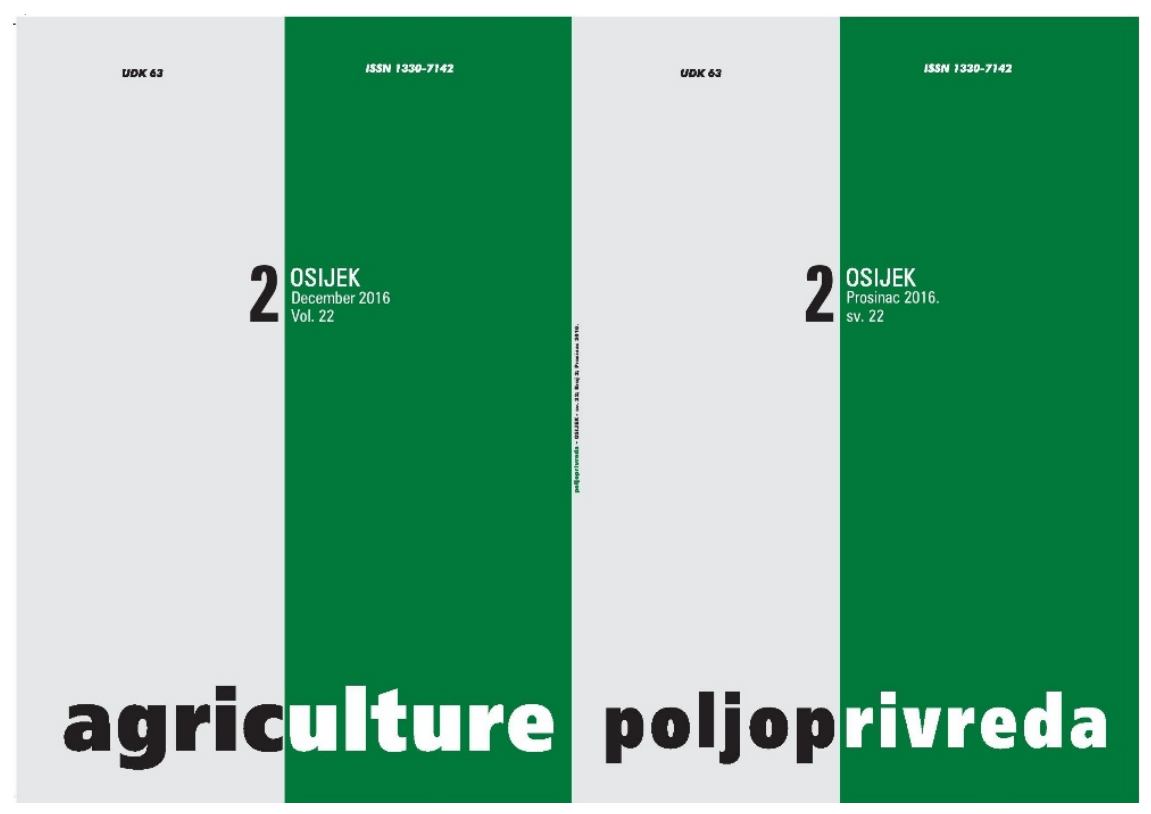

Poljoprivredni fakultet u Osijeku, Poljoprivredni institut Osijek

Faculty of Agriculture in Osijek, Agricultural Institute Osijek 


\title{
FAUNA OF GROUND-DWELLING ARTHROPODS IN VINEYARDS OF ZADAR COUNTY (CROATIA)
}

\author{
Franin, K., Kuštera, G., Šišeta, F.
}

\section{Preliminary communication Prethodno priopćenje}

\begin{abstract}
SUMMARY
Farming practices as well as land-use management have a great impact on biodiversity and composition of ground-dwelling arthropods. In this study, abundance and diversity of spiders and epigeic soil insects in three vineyards in Zadar County (Croatia) were researched. In each vineyard 16 pitfall traps were placed, 4 in one row at the distance of $3 \mathrm{~m}$. Samples were taken every fifteen days from the beginning of May till the end of October in 2014. A total of 469 individuals belonging to 6 orders and 23 families were collected. Significant differences were found among arthropod orders. The most abundant taxonomic group was Hymenoptera (38.8\%), followed by Coleoptera (31.98\%) and Araneae (27.93\%). The highest number of specimens (232) was recorded in the integrated vineyard, whereas in the conventional vineyard on karst only 63 individuals were found. However, these results showed significant differences in arthropod assemblage between integrated and conventional vineyards. Richness and diversity (Shannon Diversity Index) were highest in the integrated vineyard (2.36) as opposed to the conventional vineyard Zaton (2.23). Our results confirmed the importance of ground cover, in particular weeds, on arthropod abundance and diversity.
\end{abstract}

Key-words: vineyard, integrated, conventional, weeds, spiders, insects

\section{INTRODUCTION}

Agricultural intensification throughout cropland expansion, application of mineral fertilizers and pesticide input, as well as intensive tillage, has caused rapid loss of semi-natural habitats and natural enemies of agricultural pests (Sharley et al., 2008; Zhao et al., 2015). Intensive tillage (methods used, frequency and number of operation) may also have effects on arthropod population due to mechanical damage, greater exposure to predation or their emigration to adjacent habitats (Rusch et al., 2010). One of the main problems of modern agriculture, especially viticulture, is a production based on monoculture. Monoculture vineyards exhibited lower number of species, especially predators and parasitoids and correspond higher densities of main grape pests than diverse vineyard agroforest (Altieri and Nicholls, 2002; Williamson and Johnson, 2005). However, monoculture leads to landscape simplification and can cause decreasing of predatory arthropod population. According

Kristijan Franin, dipl. ing. agr. (kfranin@unizd.hr), Gabrijela Kuštera, univ. bacc. ing. agr., Frane Sišeta, student - University of Zadar, Department of Ecology, Agronomy and Aquaculture, Croatia to Zhao et al. (2013) ground-dwelling arthropods have significant functions in an agroecosystem, such as pest control and food chain maintenance. Nicholls et al. (2008) reported that there are many ways in which enhanced plant biodiversity can contribute to the design of pest-stable agroecosystem.

Many producers manage cover crops vegetation to increase natural enemy population. Aside from selected cover crops, weeds also play an important role in enhancing the abundance and diversity of arthropod predators and can serve as a source of increased diversity in agroecosystems. In many agroecosystems, weeds are ever-present biological components within and around fields (Nicholls and Altieri, 2012). Both spider and predaceous insects play an important role in biological control of harmful organisms in vineyards and often dominate in vineyard agroecosystems (Bolduc et al., 2005; Chatterjee et al., 2009; Costello and Daane, 1998). They might contribute to the control of some economically important pests such as mealybugs, leafrollers, leafhoppers and planthoppers (Daane et al., 2008). Other than spiders, some coleopteran families such as Carabidae and Staphylinidae are one of the 
most important insects in vineyard agroecosystem. Paoletti and Lorenzoni (1989) found Staphylinidae to be valuable predators of phytophagus mites. Wiliamson and Johnson (2005) showed more carabids in a conventional than in an abandoned vineyard where insecticides were not used. According to Rosado et al. (2012), ants also play an important role in vineyard agroecosystems. Moreover, they have often been referred to as good bioindicators of land use, soil disturbance and habitat quality (Addison et al., 2013). In this paper, we focused on the abundance and diversity of ground-dwelling arthropods in vineyards under different management practices. The main aim of this research was to help understand the role of vineyard practices and in particular the soil management on epigeic arthropods fauna.

\section{MATERIAL AND METHODS}

\section{Localities of research}

Research was conducted in vineyards near Zadar (Northern Dalmatia, Croatia). Three different vineyards according to the farm practices and soil management were chosen (Table 1). Two under conventional and one under integrated production system. In the integrated vineyard (Baštica), the soil was covered with weeds and mowed several times during the growing period. The conventional vineyard on karst (Punta Skala) was planted on exceedingly stony soil (15-50\% surface covered with stones). Mechanical weed control was performed with the special tool adopted to a high content of rocks. In the conventional vineyard (Zaton), the soil was characterized as Red Mediterranean soil (Terra Rossa). The soil surface of this site contained less than $3 \%$ of stones (moderately stony). In all vineyards pesticides were applied against major grape pests.

\section{Arthropods collection and identification}

Arthropod sampling was done every 15 days between May and October in 2014. In each vineyard, on the surface of approximately 1 ha, a total of 16 pitfall traps were placed, four in one row. Traps were arranged in a grid $(4 \times 4)$ and separated by $3 \mathrm{~m}$. Plastic cups 10 $\mathrm{cm}$ deep, and $9 \mathrm{~cm}$ in diameter were filled with approximately $200 \mathrm{ml}$ solution of ethylen-glicol and water (1:1). In each trap two drops of detergent were put to reduce the surface tension. Samples were taken after $48 \mathrm{~h}$ and preserved in $70 \%$ ethyl alcohol. Arthropod fauna was identified to the family level. For determinations Schmidt (1970) and Roberts (1996) keys were used.

Table 1. Localities of research, soil management, farm practices and coordinates

Tablica 1. Lokaliteti istraživanja, način proizvodnje, gospodarenje tlom i koordinate

\begin{tabular}{|l|l|c|c|c|}
\hline $\begin{array}{l}\text { No. } \\
\text { Broj }\end{array}$ & $\begin{array}{l}\text { Locality } \\
\text { Lokalitet }\end{array}$ & $\begin{array}{c}\text { Production } \\
\text { Način proizvodnje }\end{array}$ & $\begin{array}{c}\text { Soil management } \\
\text { Gospodarenje tlom }\end{array}$ & $\begin{array}{c}\text { Coordinates } \\
\text { Koordinate }\end{array}$ \\
\hline 1. & Baštica & Integrated & Cover crops & $44^{\circ} 09^{\prime} 30^{\prime \prime} \mathrm{N} 15^{\circ} 26^{\prime} 07^{\prime \prime} \mathrm{E}$ \\
\hline 2. & Zaton & Conventional & Tillage & $44^{\circ} 13^{\prime} 05^{\prime \prime} \mathrm{N} 15^{\circ} 11^{\prime} 30^{\prime \prime} \mathrm{E}$ \\
\hline 3. & Punta skala & Conventional & Tillage & $44^{\circ} 11^{\prime} 26^{\prime \prime} \mathrm{N} 15^{\circ} 10^{\prime} 07^{\prime \prime} \mathrm{E}$ \\
\hline
\end{tabular}

\section{Statistical analysis}

Nonparametric ANOVA on Ranks (Kruskal-Wallis test) was used to compare the abundance of arthropods among localities. Post hoc comparisons were done using the Tukey's test. Biodiversity analyses for each site were estimated using biodiversity indices. Diversity among vineyards was compared using Shannon Diversity Index $\left(\mathrm{H}^{\prime}\right)$, which is based on the number of individuals at the family level. Similarity among vineyards was compared using Sörensen Index of Similarity (Magurran, 2004). Analyses were performed with the SigmaPlot 11 statistical package (Systat Software).

\section{RESULTS AND DISCUSSION}

We sampled a total of 469 individuals belonging to 6 orders (Araneae, Coleoptera, Hymenoptera, Hemiptera, Diptera and Lepidoptera) and 23 families (Table 2). 
Table 2. Total number of arthropods collected with pitfall traps in vineyards in Zadar County (Croatia)

Tablica 2. Ukupni broj člankonožaca sakupljen u lovnim posudama u vinogradima na području Zadarske županije (Hrvatska)

\begin{tabular}{|c|c|c|c|c|c|c|c|c|c|}
\hline \multirow{2}{*}{$\begin{array}{l}\text { Order } \\
\text { Red }\end{array}$} & \multirow{2}{*}{$\begin{array}{l}\text { Family } \\
\text { Porodica }\end{array}$} & \multicolumn{2}{|c|}{ Baštica } & \multicolumn{2}{|c|}{ Punta Skala } & \multicolumn{2}{|c|}{ Zaton } & \multicolumn{2}{|c|}{ Total/Ukupno } \\
\hline & & $\mathrm{n}$ & $\%$ & $n$ & $\%$ & $\mathrm{n}$ & $\%$ & $\mathrm{n}$ & $\%$ \\
\hline \multirow{9}{*}{ Araneae } & Agelenidae & 15 & 6.46 & 3 & 4.76 & - & - & 18 & 3.84 \\
\hline & Araneidae & - & - & - & - & 4 & 2.99 & 4 & 0.85 \\
\hline & Gnaphosidae & 9 & 3.87 & 1 & 1.58 & 21 & 12.06 & 31 & 6.61 \\
\hline & Lycosidae & 15 & 6.46 & 4 & 6.34 & 17 & 9.77 & 36 & 7.67 \\
\hline & Pisauridae & 7 & 3.01 & 6 & 9.52 & 9 & 5.12 & 22 & 4.69 \\
\hline & Salticidae & 10 & 4.31 & 2 & 3.17 & 4 & 1.72 & 16 & 3.19 \\
\hline & Sparassidae & 1 & 0.43 & 1 & 1.58 & - & - & 2 & 0.42 \\
\hline & Tetragnathidae & - & - & - & - & 1 & 0.57 & 1 & 0.21 \\
\hline & Zoropsidae & 1 & 0.43 & - & - & 1 & 0.57 & 2 & 0.42 \\
\hline \multirow{8}{*}{ Coleoptera } & Anthribidae & 1 & 0.43 & - & - & - & - & 1 & 0.21 \\
\hline & Carabidae & 14 & 6.03 & 3 & 4.76 & 1 & 0.57 & 18 & 3.83 \\
\hline & Curculionidae & 2 & 0.86 & - & - & - & - & 2 & 0.42 \\
\hline & Elateridae & 1 & 0.43 & 2 & 3.17 & 2 & 1.14 & 5 & 1.06 \\
\hline & Lucanidae & 12 & 5.17 & 4 & 6.34 & 37 & 21.26 & 53 & 11.30 \\
\hline & Scarabaeidae & 3 & 1.29 & 6 & 9.52 & 8 & 4.59 & 17 & 3.62 \\
\hline & Staphylinidae & 8 & 3.44 & 9 & 14.28 & 19 & 10.92 & 36 & 7.67 \\
\hline & Tenebrionidae & 3 & 1.29 & 8 & 12.69 & 7 & 3.01 & 18 & 3.83 \\
\hline Diptera & Muscidae & 2 & 0.86 & - & - & - & - & 2 & 0.42 \\
\hline \multirow[t]{2}{*}{ Hemiptera } & Pentatomidae & - & - & - & - & 1 & 0.57 & 1 & 0.21 \\
\hline & Cicadidae & 2 & 0.86 & - & - & - & - & 2 & 0.42 \\
\hline \multirow{2}{*}{ Hymenoptera } & Formicidae & 125 & 53.87 & 14 & 22.22 & 40 & 22.98 & 179 & 38.16 \\
\hline & Vespidae & - & - & - & - & 3 & 1.72 & 3 & 0.64 \\
\hline Lepidoptera & Tortricidae & 1 & 0.43 & - & - & - & - & 1 & 0.21 \\
\hline
\end{tabular}

Arthropod abundance differed significantly (Kruskal-Wallis test, $\mathrm{H}=18.168, \mathrm{df}=2, \mathrm{p}<0.001$ ) among localities (Figure 1). The highest number of specimens was found in the integrated vineyard covered with mostly weedy plants (232) as opposed to very low abundance in the conventional vineyard on karst (63). Arthropod fauna was numerically dominated by orders Hymenoptera (38.8\%), Coleoptera (31.94\%) and Araneae (27.90\%). Among other taxa, a few individuals of Hemiptera, Lepidoptera, Diptera and Hymenoptera (Vespidae) were also found but due to their low number, they were excluded from the analysis.

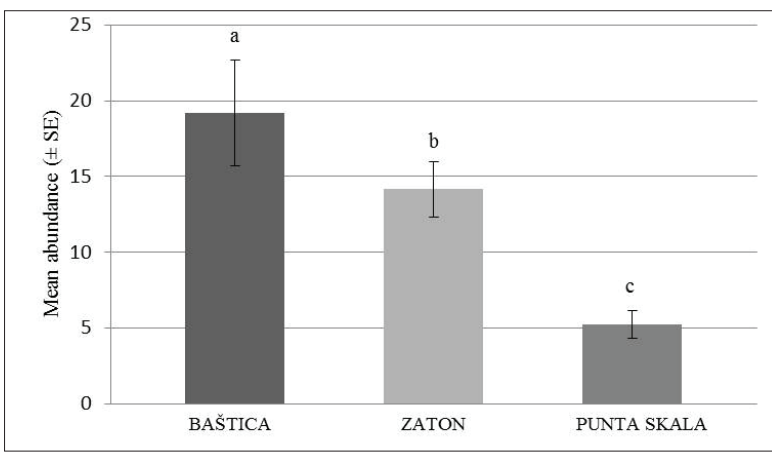

Figure 1. Comparison of captures among sites. Means with different descriptors differ significantly $(p<0.05)$

Slika 1. Usporedba ulova između lokaliteta. Različita slova iznad srednjih vrijednosti označavaju značajne razlike $(p<0,05)$

In this research, Formicidae was the most abundant family. These taxa significantly differed (KruskalWallis test, $\mathrm{H}=8.800, \mathrm{df}=2, \mathrm{p}<0,001$ ) between Baštica and Punta Skala (Figure 2). Our results agree with those 
reported by Peréz-Bote and Romero (2012). In olive orchards, ants represented between $21.3 \%$ and $31.8 \%$ of predator capture (Gonçalves and Pereira, 2012). The study of Sharley et al. (2008) showed that several ants genera were affected by tillage in vineyards. That could explain lower number of ants in vineyards Punta skala and Zaton.

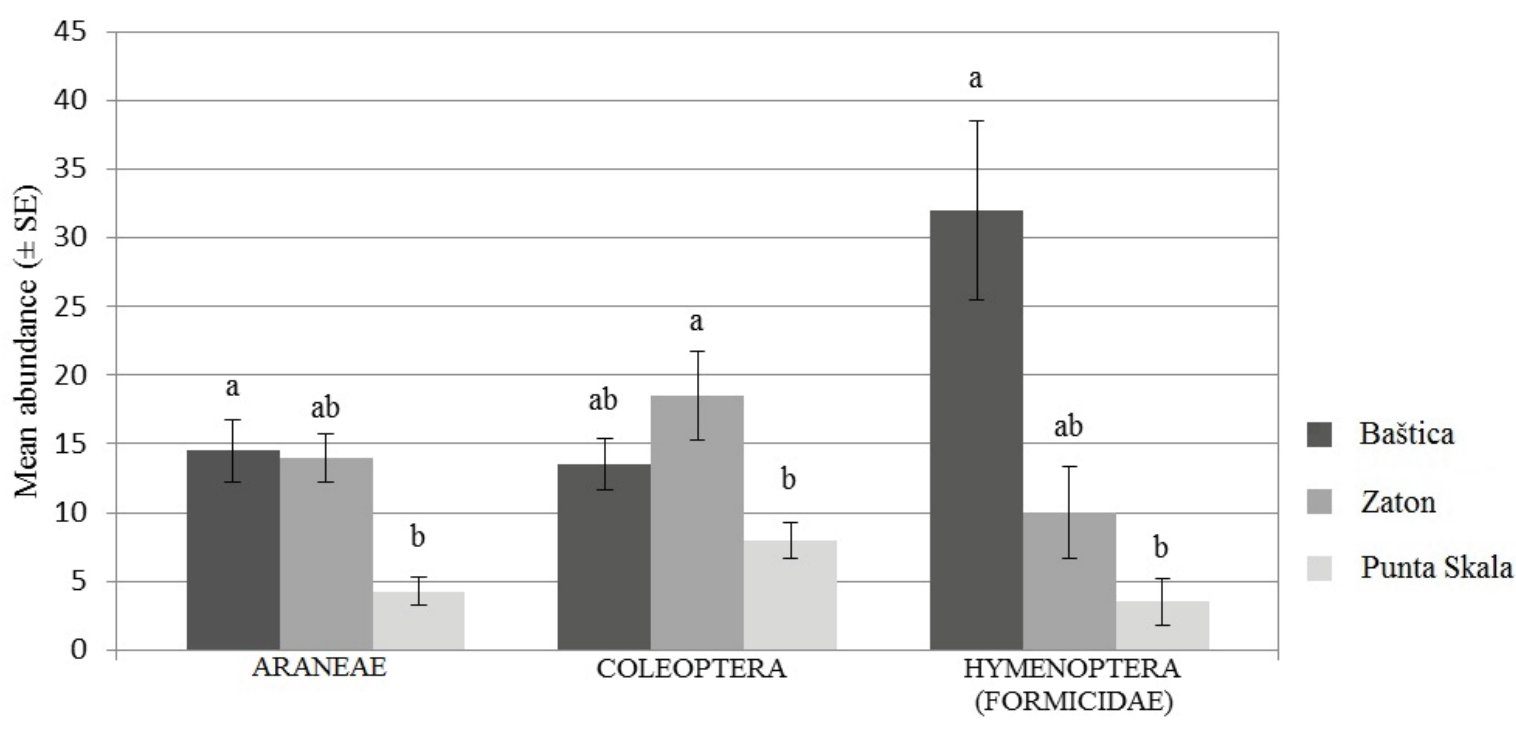

Figure 2. Comparison among arthropod orders. Means with different descriptors differ significantly $(p<0.05)$

Slika 2. Usporedba ulova između redova člankonožaca. Različita slova iznad srednjih vrijednosti označavaju značajne razlike $(p<0,05)$

Doblas-Miranda et al. (2007) also confirmed domination of Formicidae and Coleoptera in Mediterranean agroecosystems. Coleoptera showed significant differences (Kruskal-Wallis test, $\mathrm{H}=6.6478, \mathrm{df}=2, \mathrm{p}<0,001$ ) between Zaton and Punta Skala (Figure 2). In conventional vineyards Zaton and Punta Skala Lucanidae showed the highest abundance. Roessner (2005) found these insects in orchard meadows. One of the reasons for high abundance of Lucanids might be the fact that vineyards are surrounded with forest. Comparing coleopteran fauna between organic and conventional orchards, Shah et al. (2003) found less staphylinids but more carabids in the organic than in the conventional orchard. Their results are similar to our data, whereas the highest abundance of Staphylinidae was detected in conventional vineyards. Our results agree well with those obtained from the research of Sharley et al. (2008). According to their data, Staphyllinidae population increased in the tilled vineyards. As far as chemical and biological insecticides in vegetable production are concerned, the spider number was lower when chemical insecticides were used, while carabids were not affected by insecticides (Hummel et al., 2002). Gaigher and Samways (2010) indicated the importance of weed cover on arthropod abundance, although the same authors found no significant differences between organic and integrated vineyard in arthropod assemblage. Bruggiser et al. (2010) investigated the effect of vineyard management on arthropods biodiversity and they found no differences in species richness between conventional and organic vineyard. We could conclude that weeds play an important role in arthropod density and diversity. Plant diversity increases pray availability as well as spider abundance and richness. Significant differences were also found in spider composition (Kruskal-Wallis test, $\mathrm{H}=7.499, \mathrm{df}=2, \mathrm{p}<0,001$ ) between Baštica and Punta Skala. In evaluating the influence of insecticide chlorpyrifos on spider abundance, Fountain et al. (2007) found no significant differences between insecticide treatments and control. Spider community in vineyards was mainly composed of Gnaphosidae and Lycosidae (Bosco, 2014; Gaigher and Samways, 2014). In our research the highest percentage of specimens showed Lycosidae (7.67\%), Gnaphosidae (6.61\%) and Agelenidae (3,84\%). Costello and Daane (1998) comfirmed no significant differences in number of spiders between vineyards with ground cover and clean cultivated vineyards. Shannon Diversity Index showed maximum value (2.36) in the integrated vineyard, whilein the conventional one (Zaton) Shannon Diversity Index was 2.23 (Figure 3). According to Sörensen Index of Similarity, the highest values $(0.40)$ were found between the conventional vineyard on karst and the integrated one. 


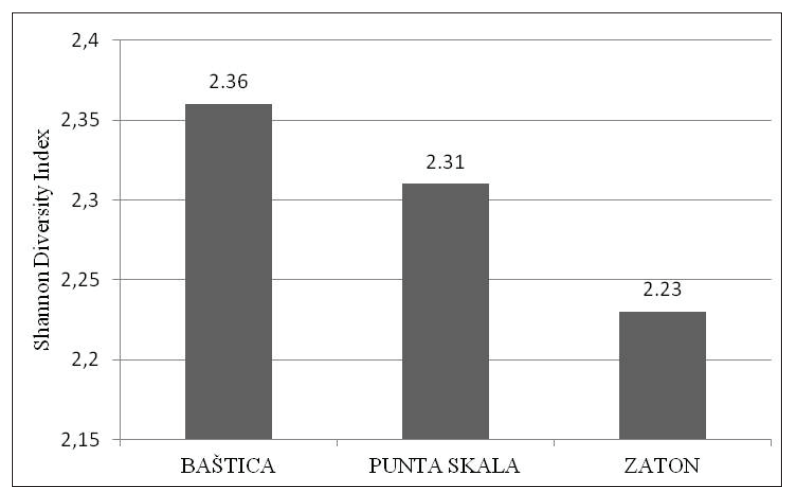

Figure 3. Shannon Diversity Indeks ( $\mathrm{H}^{\prime}$ ) among localities

Slika 3. Shannon Diversity Indeks (H') između lokaliteta

Arthropod community in this research was mainly composed of potential predators. According to data of Santos et al. (2007), tillage within vineyards systems lead to disruption of epigeic and soil arthropods (ants, centipedes and millipedes). We also found less insects and spiders in the tilled vineyard. Moreover, the lowest number of specimens was noticed in the conventional vineyard on ameliorated karst. There are two possible explanations for this situation. First, in this vineyard pesticides were used. Chemical treatment, especially herbicide sprays as well as mineral fertilizers, have a negative effect on ground-dwelling predators (Minarro et al., 2009). The second reason was possibly very low amount of organic material and high content of stones $(>50 \%)$ in this soil. According to Gonçalves and Pereira (2012), a high number of stones and near-complete absence of weeds also affected low number of soil fauna in olive orchard.

\section{CONCLUSION}

Arthropod assemblage composition between integrated and conventional vineyards showed significant differences. Ecological infrastructure in the integrated vineyard as well as the type of production has great influence on arthropods fauna. Vineyards with cover plants support higher abundance and diversity of spiders and insects. Our data indicate that an integrated vineyard with higher vegetational complexity provides better conditions (habitat, food and alternative prey) for arthropods. Agricultural intensification, disruptive practices such as soil tillage, absence of weed cover, high input of pesticides and mineral fertilizers can cause arthropod mortality and reduce their abundance. We suggest some interventions be made in vineyards on karst, such as introducing wildflower strips and weedy patches, which could help in enhancing biodiversity of ground-dwelling arthropods.

\section{REFERENCES}

1. Addison, P., Baauw, A.H., Groenewald, G.A. (2013): An Initial Investigation of the Effects of Mulch Layers on Soil-Dwelling Arthropod Assemblages in Vineyards. South African Journal of Enology and Viticulture, 34(2): 266-271.

2. Altieri, M.A., Nicholls, C.I. (2002): The simplification of traditional vineyard based agroforests in northwestern Portugal. Some ecological implications. Agroforestry Systems, 56: 185-191. doi: http://dx.doi.org/10.1023/A:1021366910336

3. Bolduc, E., Buddle, C.M., Bostanian, N.J., Vincent, C. (2005): Ground-Dwelling Spider Fauna (Aranea) in Two Vineyards in Southern Oebec. Environmental Entomology, 34(3): 635-645.

4. Bosco, L. (2014): The effect of ground vegetation cover on vineyard habitat use by the woodlarl Lullula arborea and its arthropod prey. Master Thesis. University of Bern.

5. Bruggisser, O.T., Schmidt-Entling, M.H., Bacher, S. (2010): Effects of vineyard management on biodiversity at three trophic levels. Biological Conservation. 143: 1521-1528. doi: http://dx.doi.org/10.1016/j.biocon.2010.03.034

6. Chatterjee, S., Isaia, M., Venturio, E. (2009): Spiders as biological controllers in the agroecosystem. Journal of Theoretical Biology, 258: 352-362.

7. Costello, M.J., Daane, K.M. (1998): Influence of ground cover on spider populations in a table grape vineyard. Ecological Entomology, 23: 33-40.

doi:http://dx.doi.org/10.1046/j.1365-2311.1998.00108.x

8. Daane, K.M., Cooper, M.L., Triaptsyn, S.V., Walton, V.M., Yokota, G.Y., Haviland, D.R., Bentley, W.J., Godfrey, K.E., Wunderlich, L.R. (2008): Vineyard managers and researches seek sustainable solutions for mealybugs, a changing pest complex. California Agriculture, 62: 167176. doi: http://dx.doi.org/10.3733/ca.v062n04p167

9. Doblas-Miranda, E., Sánchez-Piñero, F., GonzálesMegías, A. (2007): Soil macroinventebrate fauna of a Mediterranean arid system: Composition and temporal changes in the assemblage. Soil Biology and Biochemistry, 39: 1916-1925. doi: http://dx.doi.org/10.1016/j.soilbio.2007.02.009

10. Fountain, M.T., Brown, V.K., Gange, A.C., Symondson, W.O.C., Murray, P.J. (2007): The effects of the insecticide chlorpyrifos on spider and Collembola communities. Pedobiologia, 51(2): 147-158. doi: http://dx.doi.org/10.1016/j.pedobi.2007.03.001

11. Gaigher, R., Samways, M.J.( 2010.):Surface-active arthropods in organic vineyards, integrated vineyards and natural habitat in the Cape Floristic Region. Insect Conservation and Diversity, 14: 595-605. doi: http://dx.doi.org/10.1007/s10841-010-9286-2

12. Gaigher, R., Samways, M. (2014): Landscape mosaic attributes for maintaining ground-dwelling spider diversity in a biodiversity hotspot. Insect Conservation and Diversity, 7: 470-479. doi: http://dx.doi.org/11/icad.12070 
13. Gonçalves, M.F., Pereira, J.A. (2012): Abundance and diversity of soil arthropods int he olive grove ecosystem. Journal of Insect Science, 12(20): 1-14. doi: http://dx.doi.org/10.1673/031.012.2001

14. Hummel, R.L., Walgenbach, J.F., Hoyt, G.D., Kennedy, G.G. (2002): Effects of vegetable production systems on epigeal arthropod populations. Agriculture, Ecosystem and Environment, 93: 177-188. doi: http://dx.doi.org/10.1016/S0167-8809(01)00345-0

15. Magurran, A.E. (2004): Measurin Biological Diversity. BlackWell Publiscing. Oxford.

16. Miñarro, M., Espadaler, X., Melero, V.X., Suárez-Álvarez. (2009): Organic versus conventional management in an apple orchard: effects of fertilization and tree-row management on ground-dwelling predaceous arthropods. Agricultural and Forest Entomology, 11: 133-142. doi: http://dx.doi.org/10.1111/j.1461-9563.2008.00403.x

17. Nicholls, C.I., Altieri, M.A., Ponti, L. (2008): Enhancing Plant Diversity for Improved Insect Pest Management in Northern California Organic Vineyards. Acta Horticulturae, 785: 263-278. doi: http://dx.doi.org/10.17660/ActaHortic.2008.785.32

18. Nicholls, C.I., Altieri, M.A. (2012): Plant biodiversity enhanced bees and other pollinators in agroecosystems. A review. Agronomy for Sustainable Development, 33(2): 257-247. doi: http://dx.doi.org/10.1007/s13593-012-0092-y

19. Paoletti, M.G., Lorenzoni, G.G. (1989): Agroecology patterns in northeastern Italy. Agriculture, Ecosystem and Environment, 27: 139-154. doi: http://dx.doi.org/10.1016/0167-8809(89)90080-7

20. Pérez-Bote, J.L., Romero, A.J. (2012): Epigeic soil arthropod abundance under different agricultural land uses. Spanish Journal of Agricultural Research, 10(1): $55-61$. doi: http://dx.doi.org/10.5424/sjar/2012101-202-11

21. Roberts, M.J. (1996): Spiders od Britan and Northern Europe. HarperCollins Publishers. London.

22. Roessner, E. (2005): Extensively pastured orchard meadows in the Grabfeld Thuringia as attracitve habitats for scarabeid and lucanid beetles Coleoptera. Theuringer Faunistische Abhandlungen, 10: 215-222.

23. Rosado, J.L.O., de Gonçalves, M.G., Dröse, W., de Silva E.J.D., Krüger, R.F., Feitosa, R.M., Loeck, A.E. (2012): Epigeic ants (Hymenoptera: Formicidae) in vineyards and grasslands areas int he Campanha region, state of Rio Grande do Sul, Brazil. Journal of Species List and Distribution, 8(6): 1184-1189.

24. Rusch, A., Valantin-Morison, M., Sarthous, J.P., RogerEstrade, J. (2010): Biological Control of Insect Pest in Agroecosystems: Effects of Crop Management, Farming Systems, and Seminatural Habitats at the Landscape Scale: A Review. Advances in Agronomy, 109: 219-259. doi: http://dx.doi.org/10.1016/B978-0-12-385040-9.00006-2

25. Santos, S.A.P., Cabanas, J.E., Pereira, J.A. (2007): Abundance and diversity of soil arthropods in olive grove ecosystem (Portugal): Effect of pitffal trap type. European Journal of Soil Biology, 43: 77-83. doi: http://dx.doi.org/10.1016/j.ejsobi.2006.10.001

26. Schmidt, L. (1970): Tablice za determinaciju insekata, Sveučilište u Zagrebu, Zagreb.
27. Shah P.A., Brooks D.R., Ashby J.E., Perry J.N., Woiwod I.P. (2003): Diversity and abundance of Coleopteran fauna from organic and conventional management systems in southern England. Agricultural and Forest Entomology, 5: 51-60.

doi: http://dx.doi.org/10.1046/j.1461-9563.2003.00162.x

28. Sharley, D.J., Hoffmann, A.A., Thomson, L.J. (2008): The effects of soil tillage on beneficial invertebrates within the vineyard. Agricultural and Forest Entomology, 10: 233-243.

doi: http://dx.doi.org/10.1111/j.1461-9563.2008.00376.x

29. Williamson, J.R., Johnson, D.T. (2005): Effect of Grape Berry Moth Management Prectices and Landscape on Arthropod Diversity in Grape Vineyards int he Southern United States. HortTechnology, 15(2): 232-238.

doi: http://dx.doi.org/10.1603/EN13033

30. Zhao, Z.H., Shi, P.J., Hui, C., Ouyang, F., Ge, F., Li, B.L. (2013): Solving the pitffalls of pitfall trapping: a two-circle method for density estimation of ground-dwelling arthropods. Methods in Ecology and Evolution, 4 (9): 865-871. doi: http://dx.doi.org/10.1111/2041-210X.12083

31. Zhao, Z.H., Hui, C., He, D.H., Li., B.L. (2015): Effects of agricultural intensification on ability of natural enemies to control aphids. Scientific Reports, 5: 8024. doi: http://dx.doi.org/10.1038/srep08024 


\section{FAUNA PRIZEMNIH ČLANKONOŽACA U VINOGRADIMA ZADARSKE ŽUPANIJE (HRVATSKA)}

\section{SAŽETAK}

Način poljoprivredne proizvodnje, kao i gospodarenje tlom, ima veliki utjecaj na bioraznolikost $i$ sastav prizemnih člankonožaca. $U$ ovome je radu istražena brojnost i raznolikost faune pauka i prizemnih kukaca u vinogradima na području Zadarske županije. U svakome je vinogradu postavljeno 16 lovnih posuda, po 4 u svaki red, na razmaku od $3 \mathrm{~m}$. Uzorci su uzimani svakih petnaest dana od početka svibnja do kraja listopada 2014. godine. Uhvaćeno je sveukupno 469 jedinki, svrstanih unutar 6 redova i 23 porodice. Uočena je statistički značajna razlika između pojedinih redova. Najveća brojnost zabilježena je kod opnokrilaca (38,8\%), kornjaša (31,98 \%) i pauka (27,93 $\%)$. Najveći broj jedinki pronađen je u integriranome vinogradu, dok su u konvencionalnome vinogradu na kršu pronađene samo 63 jedinke. Rezultati su pokazali značajnu razliku u sastavu člankonožaca između integriranoga i konvencionalnih vinograda. Najveća brojnost i raznolikost (Shannon Wiener Indeks) utvrđena je u integriranom (2,36), za razliku od konvencionalnoga vinograda Zaton (2,23). Rezultati potvrđuju važnost travnatoga pokrova, posebno korova, na brojnost i raznolikost faune člankonožaca u vinogradu.

Ključne riječi: vinograd, integrirani, konvencionalni, korovi, pauci, kukci

(Received on 18 March 2016; accepted on 19 July 2016 - Primljeno 18. ožujka 2016.; prihvaćeno 19. srpnja 2016.) 